\title{
PULL FACTORS MOTIVATING MIGRANT WORKERS: THE CASE OF HOTELS IN KUALA LUMPUR, MALAYSIA
}

\author{
Nurhazani MOHD SHARIFF* \\ School of Tourism, Hospitality \& Event Management, COLGIS, Universiti Utara Malaysia 06010, Sintok, Kedah, Malaysia, e-mail: hazani@uum.edu.my
}

Azlan ZAINOL ABIDIN

Tunku Puteri Intan Safinaz School, COB, Universiti Utara Malaysia 06010, Sintok, Kedah, Malaysia, e-mail: azlan@uum.edu.my

Nur Syafiqah ABDUL GHANI

Picoms International University College, 68100, Kuala Lumpur, Malaysia, e-mail: syafiqah@picoms.edu.my

\begin{abstract}
Citation: Mohd Shariff, N., Zainol Abidin, A., \& Abdul Ghani, N.S. (2020). PULL FACTORS MOTIVATING MIGRANT WORKERS: THE CASE OF HOTELS IN KUALA LUMPUR, MALAYSIA. GeoJournal of Tourism and Geosites, 31(3), 991-995. https://doi.org/10.30892/gtg.31309-532
\end{abstract}

\begin{abstract}
The migrant workers play vital roles in fulfilling the gaps of labor shortages particularly in the hotel industry. The increasing number of migrant workers in the hotels has led to such study on factors motivating them to work in the industry. This study highlights the significance of pull factors motivating the international migrant workers in Kuala Lumpur's hotels. Two major factors were investigated namely better employment and high wages. 1550 questionnaires were distributed to the respondents within 31 hotels in Kuala Lumpur. However, only 400 questionnaires were returned and the findings of the study indicated that both better employment and high wages are considered as significant pull factors motivating the migrant workers to work in the Kuala Lumpur's hotels. Majority agreed that the hotels in Kuala Lumpur provide better employment aspect for them such as better job opportunities, enhance employability, opportunity for career development and better life. The findings eventually contribute to the hotels' management in preparing quality amenities and providing more benefits to recruit more migrant workers in the industry.
\end{abstract}

Key words: Migrant worker, pull factors, motivating, hotel, Kuala Lumpur, Malaysia

$* \quad * \quad * \quad * \quad * \quad *$

\section{INTRODUCTION}

Migration is believed to be normally linked with the economic aspects, political instability and natural disasters in the country (Ajis et al., 2014). As for Malaysia, people migrate to the countries in search of employment, whether on a permanent or temporary basis. The foreign workers who came to Malaysia are mostly to escape from the problem such as being without a job and jobs with low salary in their home countries. This is because Malaysia is capable to fascinate the foreign workers to come due to its accessibility of jobs arising from the rapid development in various sectors (Ow et al., 2013). In a recent study, Segaran and Yahya (2018) proposed a framework on pull and push factors motivating the expatriate migrants to choose Malaysia and noted that among the pull factors are economic, safety and political stability. The findings are vital in determining the reasons for the expatriate migrants to choose Malaysia as their second home. The pull and push factors are also known as drivers or forces leading to the inception of migration (Van Hear et al., 2018).

According to Lasimbang et al., (2015), the ratio of legal and undocumented migrant in Malaysia for the year 2010 is 1:1., where about half of the 1.8 million registered migrants were from Indonesia. Most of the migrant workers in Malaysia are low skilled and contract workers who control $97 \%$ of the migrant workforce. Most of them are being employed in the manufacturing, construction, plantation, agriculture and service sectors. They are employed based on a temporary measure to overcome the labor market inequalities in specific industries among others is the food and beverage industry (Yee and Yuen, 2014). In fact, a study by Datu Eranza and Awang Razli (2013) found that foreign employees in hotels in Kuala Lumpur and Sabah are able to comprehend the issue of less local working in the industry. The study also suggested that social adjustment with willingness to learn are major factors motivating them to work in the industry.

At different levels in most countries, migrant worker plays a vital role in the workforce in the hotel industry (Baum, 2012). A study conducted by Rahovan (2013) found that it is necessary to encourage the hoteliers to affiliate their hotel unit to national and international hotel chains not only to benefit from consistent financial resources, but to benefit of professional management assistance from the head company and to improve the resistance to economic fluctuations in conditions of an insecure business environment. This aspect eventually leading to migration among international workers into the industry. Besides the economic growth, there are other pull factors that attract high flow of international migration into Malaysia for instance stable political situation, harmonious community, higher wages, better working and living conditions (Marwan, 2011). As noted by Monterrubio and Espinosa (2013), low-wage occupations, casual employment, low skill levels and gender segregated jobs have been commonly reported as characteristics of tourism employment. However, these characteristics of tourism employment will vary among destinations and depend largely on the socioeconomic and cultural conditions of each locality.

Previously, Marwan (2011) agreed that besides strong economic growth rate, stable political situation, harmonious community, better working and living conditions, higher wages and better employment are also among the factors that have attracted the high flow of international migration into Malaysia. The seeking of higher wages is the most noticeable and common reason given which triggers international workers to migrate (Wickramasekera, 2002). These workers might leave after they have established as either skilled or semi-skilled for a better employment opportunity and search for other firms to get an improved and increased salary.

Currently, the number of hotels in the country has gradually risen over the past 10 years till 2018. In March 2018, the number of hotels in Malaysia was reported as 3,136.000 units compared to December 2017 with only 3,126.000 units. Previously, at the en d of 2017 there was a total of 3,126 hotels (246,564 rooms), which was an addition of 247 hotels or $8.58 \%$ growth from 2,879 hotels $(212,437$ rooms) recorded by the National Property Information Centre (NAPIC, 2017).

\section{LITERATURE REVIEW}

Yee and Yuean (2014) define migrant worker as a foreigner who is involved or has been involved in a waged doings in a state of which

\footnotetext{
* Corresponding author
} 
he or she is not a citizen. Further, in a study by Thet (2014), migration is observed as a exertion of people movement from one place to other places, further, broadly related to change in permanent place of residency. Also, Rystad (1992) highlights that international migration should be known as permanent phenomenon rather than for temporary period of time. Van Hear et al., (2018) in their study emphasized that migration is shaped by a combination of conditions, circumstances and environment within which people choose to move or stay put. According to the International Organization for Migration (IOM) (2010), Malaysia, Singapore and destination countries in the Middle East desire and require labor forces that are low skilled or willing to embark on low-skilled jobs that their citizens are unwilling to take at the usual wages. Higher demand for these workers in many destination countries has been the main factor that contributes to the rise of irregular migration, with the estimated number of undocumented migrant workers considerably higher than the number of documented migrants.

Ajis et al., (2014) explain that the migration of people from one country to another has turned out to be a social development process, especially in the very modest world of economic structure. This development has incidentally given an impact in context of economy, especially to individuals, and countries that export and import migrant workers. Wildsmith-Cromarty and Conduah (2015) highlight that the immigrants' personal lives in the country are referred to as 'push' factors whilst the conditions in the host community and the attitudes of established members are known as the 'pull' factors. In the context of migration, pull factor is considered as the reasons for immigrating or moving into a place because of something desirable for instance a nicer climate, better food supply, freedom, and so on. Additionally, Cakar (2020) studied the pull and push factors of tourists visiting dark tourism and named the themes as family, media, reference group, knowledge, participation and education. In the form of travel, pull factors, also known as pull motivations, are the external and situational aspects for the tourist in making decision to travel to a destination (Kassean, 2013). Similarly, Khuong and Ha (2014) also describe pull factors in the form of travel by looking at the tangible resources and traveler's perception and expectation towards the destination. Further, the push and pull factors are also considered as motivational escapes of Emirati nationals to Australia (Michael et al., 2017).

Meanwhile, Hajek (2008) defines pull factor as an absolute factor in convincing immigration in labor shortage countries which is a chronic and unavoidable need for international workers. In contrast, pull factors are described by Zopiatis et al., (2014) as the positive attitudes individuals see to exist, motivating them to migrate to a particular destination. In their study, they found that local people in Cyprus did not want to involve in hospitality industry because of the lower salary. However, some of them decided to migrate because of the higher salary than their host country (Khosa and Vivence, 2014). In a study by Kainth (2009), the pull factors were found as important factors which draw the migrants move to a place, for instance higher wages, chances of better employment, improved working environments and facilities provided. In addition, the study also emphasized on factors that may attract people to other places, for instance better employment opportunities, better working conditions, facilities and attractive wages.

Ngoma and Ismail (2013) in their study found that increased wages and better job opportunities in western or Middle East countries generate motivations for skilled and educated workers coming from less developed countries. Thus, it is expected that higher wages will have a positive impact on migration. As a result, they also found that higher wages in destination countries lead to more migration. The results of the study in Kuala Lumpur by Janie et al., (2012) also indicated some of the reasons of foreign employment. The respondents from the interview agreed that the main factor for foreign employment or their willingness to migrate was because of the market salary.

\section{OBJECTIVE OF THE STUDY}

The study investigated two pull factors motivating the migrant workers to work at the hotels sector in Kuala Lumpur, Malaysia. Two propositions were hypothesized:

H1:Better employment significantly motivates migrant workers to work at hotels sector in Kuala Lumpur.

$\mathrm{H} 2$ :High wages significantly motivate migrant workers to work at hotels sector in Kuala Lumpur.

The framework of the study was presented in Figure 1.

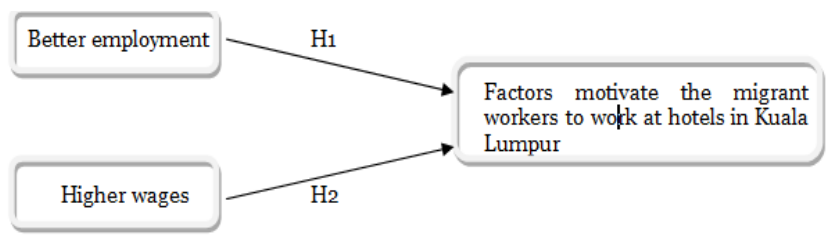

Figure 1. Framework of the study

\section{METHODOLOGY}

The study utilized a quantitative research method and had chosen Kuala Lumpur as the specific location. As noted by Segaran and Yahya (2018), the quantitative research methodology entails the collation of necessary cross-sectional data using questionnaire surveys in order to determine the causal direction and discover the existence of a causal relationship between the push and pull factors. Further, Kuala Lumpur was chosen not just based on the fact that it is the capital city of Malaysia but further due to it being the famous tourist attractions and famous destination. As the hotel industry is growing rapidly in Kuala Lumpur, there may be more international migrant workers there. Hence, the study only involved the international migrants as respondents. According to the Malaysia Association of Hotels (MAH), there are about 31 hotels with the five star ranking in Kuala Lumpur. All these hotels were selected as a unit of anaysis of the study. Each hotel was given 50 questionnaires to be distributed to the migrant workers which made it all a total of 1550 distributed questionanaires.

The data was analyzed using Statistical Package for Social Science (SPSS) latest version for Windows and descriptive analysis such as mean, frequency and percentage were used to answer the objective. Additionally, regression analysis was used to measure the hypotheses. In statistics, regression analysis includes any techniques for modeling and analyzing several variables, when the focus is on the relationship between a dependent variable and one or more independent variables. The $p$ value was tested at 0.05 which indicated that if the probability of the test statistic is less than or equal to the probability of the alpha error rate, the null hypothesis is rejected.

\section{FINDINGS}

\section{The migrant workers profiles}

The number of migrant workers in the selected 31 hotels around Kuala Lumpur area is highlighted in Figure 2. Only 400 questionnaires were returned by the hotels. Most respondents were from The Prince Hotel (14.0\%), followed by The Pullman Hotel (7.8\%), The Traders Hotel (7.5\%), The Western Hotel (6.8\%) and The Park Royal Hotel (6.0\%). 


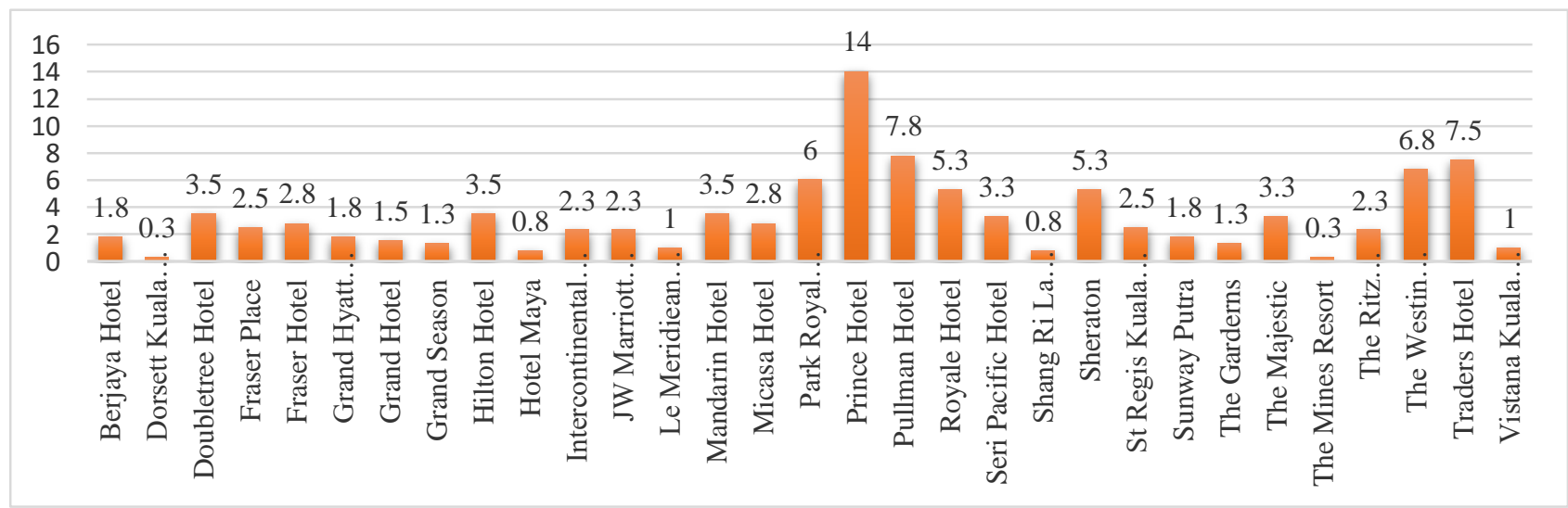

Figure 2. Number of migrant workers in Kuala Lumpur's hotels (percentage)

Table 1 depicts the findings of international migrant workers profiles. It is indicated that most respondents were male (56.5\%) compared to female $(43.5 \%)$. As for the age groups, the highest was between the age group of 20-25 years (43.5\%) and followed by $26-30$ years $(29.8 \%)$. Meanwhile, only few of the respondents were from the age group below 20 years (14.2\%) and above 30 years $(12.5 \%)$. The findings further showed that most respondents were from Indonesia (29.5\%), followed by Philippines (28.2\%), Bangladesh (20.3\%), Nepal $(13.3 \%)$, other countries (8.8\%) including respondents from India (5.5\%), Pakistan $(0.8 \%)$ and Thailand $(1.8 \%)$.

Table 1. Profiles of the respondents

\begin{tabular}{|c|l|c|c|}
\hline Item & \multicolumn{1}{|c|}{ Category } & Number & \% \\
\hline \multirow{4}{*}{ Gender } & Male & 226 & 56.5 \\
\cline { 2 - 4 } & Female & 174 & 43.5 \\
\cline { 2 - 4 } & Total & 400 & 100 \\
\hline \multirow{5}{*}{ Age } & Below 20 years & 57 & 14.2 \\
\cline { 2 - 4 } & $20-25$ years old & 174 & 43.5 \\
\cline { 2 - 4 } & 26-30 years old & 119 & 29.8 \\
\cline { 2 - 4 } & Above 30 years & 50 & 12.5 \\
\cline { 2 - 4 } & Total & 400 & 100 \\
\hline \multirow{5}{*}{ Origin } & Indonesia & 118 & 29.5 \\
\cline { 2 - 4 } & Philippines & 113 & 28.2 \\
\cline { 2 - 4 } & Bangladesh & 81 & 20.3 \\
\cline { 2 - 4 } & Nepal & 53 & 13.3 \\
\cline { 2 - 4 } & India & 22 & 5.5 \\
\cline { 2 - 4 } & Pakistan & 3 & 0.8 \\
\cline { 2 - 4 } & Thailand & 7 & 1.8 \\
\cline { 2 - 4 } & Others & 400 & 100 \\
\cline { 2 - 4 } & Total & & \\
\hline
\end{tabular}

Table 2. Mean value of better employment

\begin{tabular}{|c|l|c|}
\hline No & \multicolumn{1}{|c|}{ Mean } \\
\hline 1. & Hotels in Kuala Lumpur provide a better life for me and my family & 3.84 \\
\hline 2. & Hotels in Kuala Lumpur offer more job opportunities & 3.69 \\
\hline 3. & Hotels in Kuala Lumpur provide better working condition & 3.63 \\
\hline 4. & Hotel in Kuala Lumpur enhance employability & 3.56 \\
\hline 5. & Hotels in Kuala Lumpur have rapid industrial development & 3.55 \\
\hline 6. & Hotels in Kuala Lumpur provide better amenities & 3.50 \\
\hline 7. & Hotels in Kuala Lumpur have more prospects for a long term career development & 3.46 \\
\hline 8. & Hotels in Kuala Lumpur provide opportunity to be promoted to a better position & 3.46 \\
\hline
\end{tabular}

Perceptions of better employment as pull motivational factor

The analysis of better employment as pull factor motivating the respondents to work in Kuala Lumpur's hotels derived with high mean value ranged from $3.46-3.84$ (Table 2).

The item, hotels in Kuala Lumpur provide a better life for me and my family was rated as the most important factor whilst another item, hotels in Kuala Lumpur provide opportunity to be promoted to a better position was rated as the least important factor.

Table 3 presents the findings regarding the perceptions of better employment as pull factor motivating the migrant workers to work in the Kuala Lumpur's hotels. The items were rated according to Likert scale ranged from 1 - strongly disagreed, 2 - disagreed, 3 - unsure, 4 agreed and 5 - strongly agreed. It is indicated that most of the respondents believed that the hotels in Kuala Lumpur offer more job opportunities $(63.5 \%)$ with only few of them disagreed $(5.8 \%)$ and strongly disagreed $(1.5 \%)$. Most respondents agreed that the hotels in Kuala Lumpur offer a better life $(51.0 \%)$ and some respondents strongly agreed to the statement (15.5\%). Meanwhile, a number of respondents were unsure that the hotel industry did provide a better life for them and family $(20.8 \%)$.

Table 3. Migrant workers' perceptions on better employment

\begin{tabular}{|c|l|c|c|c|c|c|}
\hline No. & \multicolumn{1}{|c|}{ Items } & \multicolumn{3}{|c|}{ Scale } \\
\hline & \multicolumn{1}{|c|}{} & 1 & 2 & 3 & 4 & 5 \\
\hline 1. & Hotels in Kuala Lumpur offers more job opportunities & $1.5 \%$ & $5.8 \%$ & $22 \%$ & $63.5 \%$ & $7.2 \%$ \\
\hline 2. & Hotels in Kuala Lumpur provide a better life for me and my family & $2.5 \%$ & $10.3 \%$ & $20.8 \%$ & $51.0 \%$ & $15.5 \%$ \\
\hline 3. & Hotels in Kuala Lumpur enhance employability & $2.0 \%$ & $8.5 \%$ & $27.8 \%$ & $55.0 \%$ & $6.8 \%$ \\
\hline 4. & Hotels in Kuala Lumpur have rapid industrial development & $0.8 \%$ & $9.8 \%$ & $30.5 \%$ & $51.0 \%$ & $7.8 \%$ \\
\hline 5. & Hotels in Kuala Lumpur provide better working condition & $0.8 \%$ & $9.0 \%$ & $27.8 \%$ & $50.0 \%$ & $11.8 \%$ \\
\hline 6. & Hotels in Kuala Lumpur provide better amenities & $1.8 \%$ & $9.3 \%$ & $32.0 \%$ & $49.5 \%$ & $7.0 \%$ \\
\hline 7. & Hotels in Kuala Lumpur have more prospects for a long term career development & $0.8 \%$ & $15.5 \%$ & $28.5 \%$ & $48.0 \%$ & $7.2 \%$ \\
\hline 8. & Hotels in Kuala Lumpur provide opportunity to be promoted to a better position & $1.8 \%$ & $11.3 \%$ & $35.3 \%$ & $42.5 \%$ & $9.3 \%$ \\
\hline
\end{tabular}

Table 4. Mean value of high wages

\begin{tabular}{|c|l|c|}
\hline No & \multicolumn{1}{|c|}{ Mean } \\
\hline 1. & $\begin{array}{l}\text { Hotels in Kuala Lumpur have } \\
\text { encouraged me to send more } \\
\text { money back to my family }\end{array}$ & 3.78 \\
\hline 2. & $\begin{array}{l}\text { Hotels in Kuala Lumpur provide } \\
\text { a better life with the salary Ireceived }\end{array}$ & 3.73 \\
\hline 3. & $\begin{array}{l}\text { Hotels in Kuala Lumpur offer higher } \\
\text { salary compared to other industry }\end{array}$ & 3.62 \\
\hline 4. & $\begin{array}{l}\text { Hotels in Kuala Lumpur provide } \\
\text { allowances and bonuses }\end{array}$ & 3.53 \\
\hline
\end{tabular}

As for the enhancement of employability, the findings showed that the respondents believed that the hotels in Kuala Lumpur enhance employability (55.0\%), with few respondents were unsure about it $(27.8 \%)$. The findings further showed that most respondents agreed that the hotels in Kuala Lumpur have rapid industrial development $(51.0 \%)$. However, some of them were also quite unsure (30.5\%) and also strongly disagreed that the hotels in Kuala Lumpur have rapid industrial development $(9.8 \%)$. Further, the result of the analysis also highlighted that most of the respondents agreed that the hotels in Kuala Lumpur provide better working condition (50\%). Few of the respondents however disagreed with the statement $(9 \%)$ and a small number was unsure of the better working condition provided by the 
hotels $(0.8 \%)$. As for the better amenities, many respondents agreed to the statement $(49.5 \%)$. It is also noted that some of them were unsure about the statement (32\%) and only few disagreed that the hotels in Kuala Lumpur provide better amenities (9.3\%). Additionally, the findings indicated that most respondents agreed that the hotels in Kuala Lumpur have more prospect for career development (48\%) whilst few of the respondents disagreed with the statements (15.5\%). It was also found that most of the respondents agreed that the hotels in Kuala

Lumpur provide opportunity to be promoted to a better position (42.5\%). More, it was indicated from the analysis that some of them disagreed $(11.3 \%)$ and few strongly disagreed of the statement $(1.8 \%)$.

\section{Perceptions of high wages as pull motivational factor}

Additionally, it is also indicated that all the high wages items derived with high mean value ranged from $3.53-3.78$ (Table 4). Hotels in Kuala Lumpur have encouraged me to send more money back to my family was rated by the respondents as the most important factor whilst the item, hotels in Kuala Lumpur provide allowances and bonuses was rated as the least important factor.

The perceptions of high wages as pull factor were also measured using the Likert scale. Table 5 shows that majority agreed that working in the hotels in Kuala Lumpur encourage them to send money back to their family $(48.3 \%)$. However, most of the respondents were also unsure about the statement $(26.1 \%)$ whilst the remaining strongly agreed (18.8\%), disagreed $(5.8 \%)$ and few strongly disagreed with it (1\%). Further, most respondents agreed that the hotels in Kuala Lumpur offer higher salary compared to other industries (48\%). Yet, there were still few respondents unsure of the statement $(31 \%)$. Some of the respondents strongly agreed that the hotels in Kuala Lumpur offer higher salary $(11.8 \%)$ whilst several respondents disagreed $(8.8 \%)$ and only few strongly disagreed $(0.5 \%)$.

Additionally, further findings of the study indicated that most of the respondents agreed that the hotels in Kuala Lumpur provide a better life to them (46\%). Even though some respondents were unsure about the statement (28.5\%), few of the respondents still strongly agreed that the hotels in Kuala Lumpur provide them a better life (18\%). The findings of the study regarding high wages as pull factor al so depicted that most of the respondents agreed that the hotels in Kuala Lumpur provide allowances and bonuses (34.8\%) while few respondents were unsure about it (31.3\%). A small number of the respondents also disagreed that the hotels in Kuala Lumpur provide allowances and bonuses (10\%). Moreover, only a small number of the respondents strongly disagreed with the statement (5\%).

Table 5. Migrant workers' perceptions on high wages

\begin{tabular}{|c|c|c|c|c|c|c|}
\hline \multirow{2}{*}{ No } & \multirow{2}{*}{ Items } & \multicolumn{5}{|c|}{ Scale } \\
\hline & & 1 & 2 & 3 & 4 & 5 \\
\hline 1. & Hotels in Kuala Lumpur have encouraged me to send money back to my family & $1.0 \%$ & $5.8 \%$ & $26.1 \%$ & $48.4 \%$ & $18.8 \%$ \\
\hline 2. & Hotels in Kuala Lumpur offer higher salary compared to other industry & $5 \%$ & $8.8 \%$ & $31.0 \%$ & $48.0 \%$ & $11.8 \%$ \\
\hline 3. & Hotels in Kuala Lumpur provide a better life with the salary I received & $1.0 \%$ & $6.5 \%$ & $28.5 \%$ & $46.0 \%$ & $18.0 \%$ \\
\hline 4. & Hotels in Kuala Lumpur provide allowances and bonuses & $5.0 \%$ & $10.0 \%$ & $31.3 \%$ & $34.8 \%$ & $19.0 \%$ \\
\hline
\end{tabular}

Table 6. Finding of Regression Analysis - H1

\begin{tabular}{|c|c|c|c|c|c|c|c|c|}
\hline \multicolumn{9}{|c|}{ Coefficients $^{\mathrm{a}}$} \\
\hline \multirow{2}{*}{\multicolumn{2}{|c|}{ Model }} & \multicolumn{2}{|c|}{ Unstandardized Coefficients } & \multirow{2}{*}{$\begin{array}{c}\text { Standardized Coefficients } \\
\text { Beta }\end{array}$} & \multirow{2}{*}{$\mathrm{t}$} & \multirow{2}{*}{ Sig. } & \multicolumn{2}{|c|}{$95.0 \%$ Confidence Interval for B } \\
\hline & & $\mathrm{B}$ & Std. Error & & & & Lower Bound & Upper Bound \\
\hline \multirow{2}{*}{1} & (Constant) & 1.112 & .218 & & 5.102 & .000 & .683 & 1.540 \\
\hline & Better Employment & .758 & .060 & .538 & 12.653 & .000 & .641 & .876 \\
\hline
\end{tabular}

Table 7. Finding of Regression Analysis - H2

\begin{tabular}{|c|c|c|c|c|c|c|c|c|}
\hline \multicolumn{9}{|c|}{ Coefficients $^{\mathrm{a}}$} \\
\hline & \multirow{2}{*}{ Model } & \multicolumn{2}{|c|}{ Unstandardized Coefficients } & \multirow{2}{*}{$\frac{\text { Standardized Coefficients }}{\text { Beta }}$} & \multirow{2}{*}{$\mathrm{t}$} & \multirow{2}{*}{ Sig. } & \multicolumn{2}{|c|}{$95.0 \%$ Confidence Interval for B } \\
\hline & & $\mathrm{B}$ & Std. Error & & & & Lower Bound & Upper Bound \\
\hline \multirow{2}{*}{1} & (Constant) & 2.829 & .213 & & 13.261 & .000 & 2.410 & 3.249 \\
\hline & Higher Wages & .275 & .057 & .235 & 4.808 & .000 & .163 & .387 \\
\hline
\end{tabular}

\section{Findings of the Hypotheses}

Table 6 depicts the finding of regression analysis of H1: Better employment significantly motivates migrant workers to work at hotel sectors in Kuala Lumpur. The null hypothesis was rejected since the $p$-value indicated a significance level of 0.000 which is lower than 0.05 . Hence, the finding indicates that better employment significantly contributes as pull factor motivating the migrant workers to work at the hotels sector in Kuala Lumpur. Similarly, the finding of regression analysis of H2: Higher wages significantly motivate migrant workers to work at hotel sectors in Kuala Lumpur also indicated a significance level of 0.000 (Table 7). Hence, the null hypothesis was also rejected. The high wages are also significantly contributed as pull factor motivating the migrant workers to work at hotels sector in Kuala Lumpur.

\section{DISCUSSION AND CONCLUSION}

This study focuses on two components of pull factors motivating migrant workers to work in the hotel sectors in Kuala Lumpur. Generally, it is proven from the study that better employment and high wages are pull factors motivating the migrant workers to work at the Kuala Lumpur's hotels. Both the proposed hypotheses indicate significant contribution of better employment and high wages as factors motivating the migrant workers to seek for better jobs within the industry. The findings eventually support a previous study by Gheasi et al., (2014) which indicated that most international migrant workers migrate to another country because of more job opportunities which include better employment and high wages. Further, the findings are also similar to another findings by Kainth (2009) which highlight that one of the the factors that may attract people to migrate is better employment opportunities offered by other countries. Additionally, the study also noted that comparatively higher wages is one of the factors that attract the international migrant workers to migrate. The findings of this study are also in line to Segaran and Yahya (2018) where they emphasized that economic factor is the vital pull factor for migration in the case of Malaysia. More, the study significantly reveals that the employability enhancement has contributed as factor motivating migrant workers to work in the Kuala Lumpur's hotels. This probably would be the reason for them to seek better improvement in their job scope. The findings are also consistent to the previous study by Tyvimaa and Kemp (2011) which revealed that job opportunities as factor motivating the migrant workers. Kainth (2009) also highlights that the international migrant workers migrate and work in the hotel industry to progress the technological developments, industrial developments and other cultural deviations that portrays the development of modern societies worldwide. Hence, the findings are in line with the current stud y. 
Taking into account that the working condition as a motivation factor which pull the international migrant workers (Marwan, 2011), the study also discovers that better living conditions provided by the hotels in Kuala Lumpur as one of the pull factors motivating them. Further, the study has also identified that the opportunities to have a career development are very high when working in hotels in Kuala Lumpur. This is probably based on the fact that the hotels in Kuala Lumpur have better opportunities for career development. This is reliable to the study by Dzvimbo (2003) which suggested that pull factors are related to better opportunities in the host country including career prospects. It is also possible that the most important reasons which motivate the migration of skilled and unskilled workers are because they can get the opportunity to be promoted to a better position particularly in the hotel industry.

Previously, a study by Janta et al., (2011), has noted that the international migrant workers from Eastern Europe, are also capable in making money to support their studies back in their country of origin. More, Zopiatis et al., (2014) in their study stated that most migrant workers have decided to migrate because of the higher salary offered than their host country. The study concludes that the mi grant workers can have more money by working in the hotels and they can in fact send the money back to their home countries. Additionally, the allowances and bonuses provided by the hotels in Kuala Lumpur are also seen as pull factors motivating the migrant workers.

\section{CONTRIBUTION OF THE STUDY}

The findings of the study have few theoretical and practical implications. Mostly, it is consistent to the previous literatures which support better employment and higher wages as the pull factors motivating the migrant workers to work in the hotel industry. In the case of hotels in Kuala Lumpur, high wages are considered vital factor by the migrant workers, hence it may assist the hotels to cater for the issue of labor shortages particularly among the local. Generally, the study also has extended the literature and research on migrant workers who migrate to Malaysia for the purpose of working in the hospitality industry. The findings of the study also provide good opportunity for the hotels in

Kuala Lumpur, Malaysia, regarding the consequences of having migrant workers to increase the performance and service quality of the hotels. Moreover, the study significantly provides the hotels management in Kuala Lumpur with more understanding, knowledge, skills and attitude of the various background regarding migrant workers and the motivational factors which pull them to work in the industry.

\section{Acknowledgements}

The study was sponsored by the Malaysian Ministry of Higher Education under the Fundamental Research Grant Scheme (FRGS) S/O code 13029.

\section{REFERENCES}

Ajis, M.N., Keling, M.F., Othman, Z., \& Shuib, M.S. (2014). The dilemma of managing foreign workers in Malaysia: opportunities and challenges. Global Journal of Human Social-Science:Political Science, 14(4), 43-53.

Baum, T. (2012). Migrant workers in the international hotel industry (No. International Migration Paper No. 112). http://www.ilo.org/sector/ Resources/publications/WCMS 180596/lang--en/index.htm

Cakar, G. (2020). Investigation of the motivations and experiences of tourists visiting the Gallipoli Peninsula as a dark tourism destination. European Journal of Tourism Research 24, 1-30.

Datu Eranza, D.R., \& Awang Razli, I. (2013). Foreign employment and employability in hotels at Kuala Lumpur and Sabah. Proceedings of the International Conference of the Asian Academy of Applied Business (AAAB).

Dzvimbo, K.P. (2003). The international migration of skilled human capital from developing countries. In improving tertiary education in Sub-Saharan Africa: things that work! Accra, 23-25.

Gheasi, M., Niikamp, P., \& Rietveld, P. (2014). A Study on undocumented migrant workers in the dutch household sector. International Journal of Manpower, 35(1/2), 103-117. https://doi.org/ 10.1108/IJM-08-2013-0196

Hajek, P.K. (2008). Migrant workers in south-east asia: economic and social inequality in Indonesia, Malaysia and Singapore. B.A. University of Central Florida.

International, L.O. (2010). Developments and challenges in the hospitality and tourism sector. CH-1211 Geneva 22, Switzerland: International Labour Office.

Janie, L.T., Datu, R.D.E., Izyanti, A.R., \& Awangku, H.B.P.B. (2012). Foreign employment and public image of hotels in Kuala Lumpur. BIMP-EAGA Conference $2012,1-8$.

Kainth, G.S. (2009). Push and pull factors of migration : a case of Brick Kiln industry of Punjab State. Asia-Pacific Journal of Social Sciences, (1), 82-116. http://www.socialsciences-ejournal.org

Kassean, H. (2013). Exploring tourists push and pull motivations to visit Mauritius as a tourist destination. African Journal of Hospitality, Tourism and Leisure, 2(3),1-13.

Khosa, R.M., \& Vivence, K. (2014). Migration reasons, traits and entrepreneurial motivation of african immigrant entrepreneurs towards an entrepreneurial migration progression. Journal of Enterprising Communities: People and Places in the Global Economy, 9(2), 132-155. http://dx.doi.org/10.1108/JEC-07-2014-0011

Khuong, M.N., \& Ha, H.T.T. (2014). The influences of push and pull factors on the international leisure tourists' return intention to Ho Chi Minh City, Vietnam. A Mediation Analysis of Destination Satisfaction. International Journal of Trade, Economics and Finance, 5(6), 490-496. http://doi.org/10.7763/IJTEF.2014.V5.421

Lasimbang, H.B., Tong, W.T., \& Low, W.Y. (2015). Migrant workers in Sabah, East Malaysia: the importance of legislation and policy to upheld equity on sexual and reproductive health and rights (SRHR). Best practice \& research clinical obstetrics \& gynaecology. Kota Kinabalu, Sabah: Elsevier Ltd. http://dx.doi.org/10.1016/j.bpobgyn.2015.08.015

Marwan, N.F. (2011). Macroeconomic impacts of immigration in Malaysia: trade, remittances and unemployment. Durham University.

Michael, N., Wien, C., \& Reisinger, Y. (2017). Push and pull escape travel motivations of emirati nationals to Australia. International Journal of Culture, Tourism and Hospitality Research, 11(3), 274-296. https://doi.org/10.1108/IJCTHR-04-2016-0039

Monterrubio, J.C., \& Espinosa, B. (2013). Characterizations of ecotourism employment in a developing world destination. GeoJournal Tourism and Geosites, 1(11), 54-65.

Ngoma, A.L., \& Ismail, N.W. (2013). The determinants of brain drain in developing countries. International Journal of Social Economics, $40(8)$, 744-754. http://dx.doi.org/10.1108/IJSE-05-2013-0109

Ow, C.S., Baharom, A.H., \& Habibullah, M.S. (2013). Intertemporal changes in the antecedents of migration in 1990-2000 period. the case of Malaysia and Asia-Pacific Countries. International Journal of Social Economics, 35(2008), 441-458. http://doi.org/http://dx.doi.org/10.1108/ BIJ-10-2012-0068

Rahovan, A. (2013). Translavania hotels and their economic impacts on tourism. GeoJournal of Tourism and Geosites, 2(12), 163-174.

Rystad, G. (1992). Immigration history and the future of international migration. Migration Review, 26(4), 1168-1199. http://www.jstor.org/ stable/2546879

Segaran, R.R.K., \& Yahya, S. (2018). An analysis of push and pull factors motivating expatriate migrants to contemplate Malaysia as their second home: a conceptual paper. Journal of Business and Social Development, 6(1), 130-148.

Thet, K.K. (2014). Pull and push factors of migration: a case study in the urban area of Monywa Township, Myanmar. https://www. Semantic scholar.org/paper/Pull-and-Push-Factors-of-Migration-\%3A-A-Case-Study-\%2C/2a5f1804aea79ac313dedd6fa9b49005 ae7f724d.

Tyvimaa, T., \& Kemp, C.L. (2011). Finnish seniors' move to a senior house: examining the push and pull factors. Journal of Housing For the Elderly, 25(1), 50-71. from http://doi.org/10.1080/02763893.2011.545742

Van Hear, N, Bakewell, O. \& Long, K. (2018). Push-pull plus: reconsidering the drivers of migration. Journal of Ethnic and Migration Studies, 44(6), https://doi.org/10.1080/1369183X.2017.1384135

Wickramasekera, P. (2002). Asian labour migration: issues and challenges in an era of globalization. International Migration Paper. Geneva: International Migration Office.

Wildsmith-Cromarty, R., \& Conduah, A.N. (2015). 'Push' and 'pull' factors influencing the learning of destination languages by immigrants. South African Journal of African Languages, 35(2), 147-155.

Yee, Y.S., \& Yuen, J.L.F. (2014). The recruitment of migrant workers in the food service industry in Malaysia. a study of Old Town White Coffee and Pappa Rich Kopitiam. International Journal of Business, Economics and Management, 1(10), 291-304.

Zopiatis, A., Constanti, P., \& Theocharous, A.L. (2014). Migrant labor in hospitality: the Cyprus experience. International Journal of Hospitality Management, 37, 111-120. http://doi.org/10.1016/j.ijhm.2013.11.002

*** National Property Information Centre (Napic) (2017). https://www. edgeprop/my/content/1350899/hotel-mushrooming- Malaysia

Article history: Received: 12.12.2019 Revised: 02.06.2020 